\title{
CNS Lymphocytic Vasculitis in a Young Woman With COVID-19 Infection
}

Garrett M. Timmons, MD, * Torge Rempe, MD,* Elizabeth A. Bevins, MD, PhD, Vanessa Goodwill, MD, Annalise Miner, Arthur Kavanaugh, MD, Michele Ritter, MD, and Jennifer S. Graves, MD, PhD, MAS

Neurol Neuroimmunol Neuroinflamm 2021;8:e1048. doi:10.1212/NXI.0000000000001048

Infection with severe acute respiratory syndrome coronavirus 2 (SARS-CoV-2) has been associated with several neurologic manifestations including the development of cerebral lesions resembling CNS vasculitis in elderly patients with severe coronavirus disease 2019 (COVID19). ${ }^{1-4}$ Here, we report additional evidence for COVID-19-related CNS vasculitis, confirmed by biopsy, in a young healthy patient with otherwise mild COVID-19 infection.

\section{Case Report}

A 26-year-old woman experienced 4 days of anosmia, dysgeusia, malaise, and fatigue 6 days after an airplane flight in mid-March 2020. Approximately 2-3 weeks later, she noticed difficulty keeping "flip-flops" on her left foot slowly progressing to dragging of her left foot in July 2020. Neurologic examination revealed left pyramidal tract dysfunction with left-sided weakness (4+/ 5 Medical Research Council Scale of left elbow flexion, hip flexion, knee flexion, and foot dorsiflexion) and hyperreflexia (3+ in biceps, brachioradialis, triceps, patellar, and Achilles reflexes with unsustained foot clonus and pathologic reflexes). The rest of her examination was normal, and she denied headache or any change in mental status or cognition.

Her initial brain MRI demonstrated multiple, irregular, peripherally enhancing lesions clustered within the right frontoparietal white matter. These lesions also had peripheral diffusion restriction and surrounding T2/fluid-attenuated inversion recovery hyperintensity suggestive of edema and internal susceptibility likely reflective of blood products (Figure, A, B, F, G). Cervical spine MRI was normal. CSF analysis showed a cell count of $1 / \mathrm{mm}^{3}$, protein level of $29 \mathrm{mg} / \mathrm{dL}$, and glucose of $59 \mathrm{mg} / \mathrm{dL}$. SARS-CoV-2 PCR testing was not available during the episode of presumed COVID-19 symptoms in March 2020 and was nonreactive in August 2020 during her initial hospitalization. SARS-CoV-2 antinucleocapsid antibody testing was significant for 2 positive test results (Roche assay) in September 2020, although she had negative results in simultaneously obtained additional serologic assays (Diazyme, Abbott; Figure, K). No SARS-CoV-2 PCR was performed in the CSF. Evaluation in a COVID-19 infectious disease clinic resulted in confirmation of a prior COVID-19 infection by clinical criteria. Otherwise, extensive laboratory workup of the patient's serum and CSF for other infectious, neoplastic, or autoimmune causes was negative.

Stereotactic biopsy of one of the right frontoparietal lesions demonstrated findings consistent with lymphocytic vasculitis, including infiltration of vessel walls by lymphocytes (predominantly $\mathrm{CD}^{+}{ }^{+}$mixture of $\mathrm{CD}^{+}$and $\left.\mathrm{CD} 8^{+}\right] \mathrm{T}$ cells with a sparse admixture of $\mathrm{CD} 2 \mathrm{O}^{+}$ $B$ cells) with endothelial hypertrophy. In addition, edematous and gliotic white matter changes with extensive lymphoplasmacytic perivascular inflammation were noted, along with parenchymal necrosis and abundant dystrophic calcification. No viral inclusions were seen (Figure, L-V).

\author{
Correspondence \\ Dr. Graves \\ jgraves@ucsd.edu
}



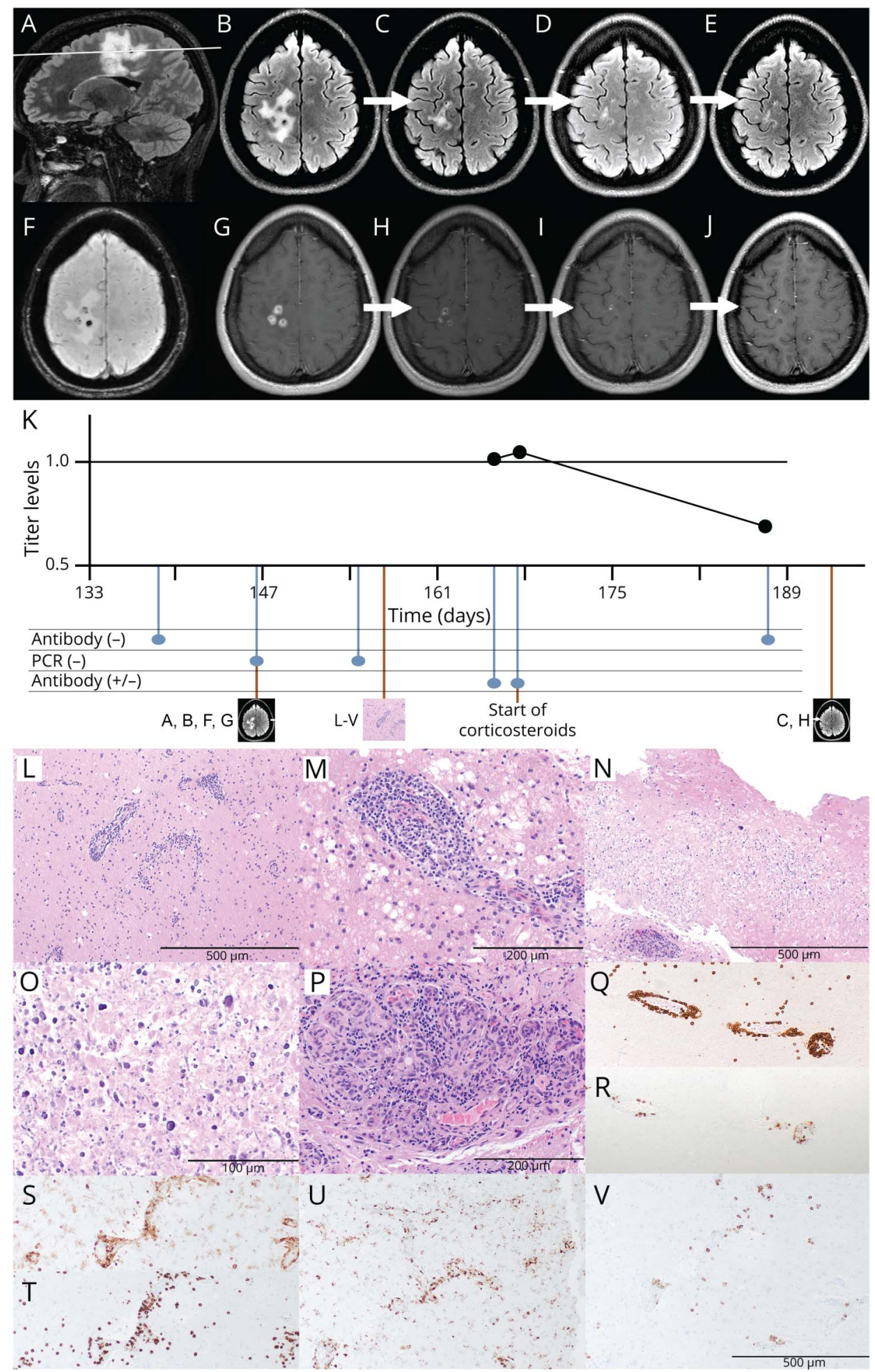

(A, B, F, G) Initial brain MRI (5 months after presumed COVID-19 infection). The white line in A depicts the level of the axial sections in B-D. Sagittal (A) and axial (B) T2/FLAIR, susceptibilityweighted ( $F$ ), and gadolinium-enhanced T1-weighted (G) sequences show multiple peripherally irregularly enhancing ovoid lesions within the right frontoparietal white matter with surrounding T2/FLAIR hyperintensity suggestive of vasogenic edema. ( $\mathrm{C}-\mathrm{E}$, $\mathrm{H}-\mathrm{J})$ Repeat MRI at $1(\mathrm{C}, \mathrm{H}), 3(\mathrm{D}, \mathrm{I})$, and 6 $(E, J)$ months after the initiation of steroid treatment. Axial T2/FLAIRweighted (C-E) and contrast-enhanced T1-weighted $(\mathrm{H}-\mathrm{J})$ sequences show a decreased size of T2/FLAIR hyperintensities and decreased contrast enhancement. (K) Time course and results of antinucleocapsid SARS-CoV-2 antibody testing. Time is shown as days since COVID-19 infection. The upper graph depicts the time course of available Roche titer levels (1.03, 1.05, and 0.7 ; the assay's cutoff of 1.0 is marked as a solid black line). Time point of initial and repeat MRI, biopsy, and initiation of corticosteroids is shown below the timeline. ( $L-V)$ Stereotactic biopsy of the right frontal lesion. (L-P) H\&Estained sections show edematous and gliotic white matter with extensive lymphoplasmacytic perivascular in flammation, as well as infiltration of vessel walls by lymphocytes, consistent with lymphocytic vasculitis (L: $\times 100 ; \mathrm{M}$ : $\times 200$ ). Multiple foci of eosinophilic coagulative necrosis with extensive dystrophic calcification were also noted (N: $\times 100 ; 0: \times 400)$. Focal endothelia swelling and hypertrophy, as well as vascular proliferation were present $(P$ $\times 200$ ). (Q-V) Immunohistochemistry showed the perivascular and intravascular lymphocytes to be predominantly CD3-positive T cells (Q: CD3 $\mathrm{IHC}, \times 100$ ) with a small subset of CD20 positive B cells (R: CD20 IHC, ×100). Numerous perivascular CD4-positive $T$ lymphocytes (S: CD4 IHC, ×100), many perivascular and parenchymal CD8positive $\mathrm{T}$ lymphocytes (T: CD8 IHC $\times 100$ ), abundant perivascular macrophages and parenchymal activated microglia (U: CD68 IHC, ×100), and scattered perivascular plasma cells (V: CD138 IHC, ×100) were observed. Special stains for bacterial and fungal organisms including Gram, AFB, GMS and HSV1/2 stains were negative (not shown) as well as tissue cultures. No viral inclusions were seen. AFB = acidfast bacteria; COVID-19 = coronavirus disease 2019; FLAIR = fluid-attenuated inversion recovery; GMS = Grocott's methenamine silver; $\mathrm{H} \& \mathrm{E}=$ hematoxylin and eosin; HSV = herpes simplex virus; $\mathrm{IHC}=$ immunohistochemistry.

The patient was treated with IV methylprednisolone $1,000 \mathrm{mg}$ daily for 3 days, followed by an oral prednisone taper over 6 months starting at $60 \mathrm{mg}$ daily. After 2 months, mycophenolate mofetil was added and uptitrated over 3 weeks to $1,000 \mathrm{mg}$ twice daily with a 4-month overlap with the ongoing prednisone taper. The patient showed continued clinical improvement of her left-sided hemiparesis with minimal residual left lower extremity weakness on most recent examination. Follow-up brain MRIs at 1, 3, and 6 months after initiation of corticosteroids showed continuing decrease in the size and 
enhancement of right frontoparietal white matter lesions, with no new lesions (Figure, C-E, H-J).

\section{Discussion}

We report a case of biopsy-confirmed CNS vasculitis that shortly followed a COVID-19 infection. To our knowledge, this is the fifth reported case of COVID-19-related CNS vasculitis and the first to be confirmed by biopsy or to occur in a young patient with otherwise mild COVID-19 infection. As the patient's slowly progressive neurologic deficit began 2-3 weeks after her COVID19 infection, this temporal correlation suggests a causal relationship, although there remains diagnostic uncertainty as PCR testing was not performed during her acute infection.

Notably, all 4 previous cases demonstrating CNS vasculitis were diagnosed based solely on imaging findings with no biopsy confirmation. All 4 were older (aged 64-69 years), experienced a more severe COVID-19 infection requiring intensive care unit level care, and developed earlier severe manifestation of neurologic symptoms compared with our case. ${ }^{1-4}$

A possible underlying mechanism is an endotheliitis caused by direct SARS-CoV-2 infection of endothelial cells through binding to the angiotensin-converting enzyme 2 receptor, which has been shown in renal, gastrointestinal, pulmonal, and cerebral vasculature. ${ }^{5,6}$ Alternatively, a proinflammatory state may have unmasked a primary CNS vasculitis. Interesting differences between this case and typical primary CNS vasculitis include the lack of headache or alteration in mental status/cognition, although a variety of phenotypes can be seen in this condition. Regardless of the mechanism, our case demonstrates that young patients with mild COVID-19 infection are still at risk for neurologic complications. Further studies of long-term outcomes in similar cases are needed to optimize the choice and duration of immunosuppression.

\section{Acknowledgment}

The authors thank the UC San Diego Neuropathology Division Fund for making possible the immunohistologic stains included in this article.

\section{Study Funding}

The authors report no targeted funding.

\section{Disclosure}

The authors declare that they have no competing interests. Unrelated to the work, the authors declare the following: G.M. Timmons reports no disclosures relevant to the manuscript. T. Rempe receives grant funding from the National MS Society. E.A. Bevins, V. Goodwill, and A. Miner report no disclosures relevant to the manuscript. A. Kavanaugh conducted research sponsored by AbbVie, Amgen, Eli Lilly, Novartis, and Pfizer. M. Ritter reports no disclosures relevant to the manuscript. J.S. Graves over the past year has grant/ contract research support from the National MS Society, Biogen, and Octave Bioscience. She serves on a steering committee for a trial supported by Novartis; she has received honoraria for a nonpromotional, educational activity for Sanofi-Genzyme; and she has received speaker fees from Alexion and BMS and served on an advisory board for Genentech. Go to Neurology.org/NN for full disclosures.

\section{Publication History}

Received by Neurology: Neuroimmunology \& Neuroinflammation March 12, 2021. Accepted in final form June 3, 2021.

\section{Appendix Authors}

\begin{tabular}{|c|c|c|}
\hline Name & Location & Contribution \\
\hline $\begin{array}{l}\text { Garrett M. } \\
\text { Timmons, } \\
\text { MD }\end{array}$ & $\begin{array}{l}\text { Department of Neurosciences, } \\
\text { University of California San } \\
\text { Diego, School of Medicine, La } \\
\text { Jolla }\end{array}$ & $\begin{array}{l}\text { Drafting/revision of the } \\
\text { manuscript for content, } \\
\text { including medical writing } \\
\text { for content; major role in } \\
\text { the acquisition of data; } \\
\text { study concept or design; } \\
\text { and analysis or } \\
\text { interpretation of data }\end{array}$ \\
\hline $\begin{array}{l}\text { Torge Rempe, } \\
\text { MD }\end{array}$ & $\begin{array}{l}\text { Department of Neurosciences, } \\
\text { University of California San } \\
\text { Diego, School of Medicine, La } \\
\text { Jolla; Department of } \\
\text { Neurology, University of } \\
\text { Florida, College of Medicine, } \\
\text { Gainesville }\end{array}$ & $\begin{array}{l}\text { Drafting/revision of the } \\
\text { manuscript for content, } \\
\text { including medical writing } \\
\text { for content; major role in } \\
\text { the acquisition of data; } \\
\text { study concept or design; } \\
\text { and analysis or } \\
\text { interpretation of data }\end{array}$ \\
\hline
\end{tabular}

Elizabeth A. Department of Neurosciences, Drafting/revision of the Bevins, MD, University of California San manuscript for content

PhD Diego, School of Medicine, La including medical writing Jolla for content; and major role in the acquisition of data

Vanessa Department of Pathology,

Goodwill, MD University of California San Diego, La Jolla

Drafting/revision of the manuscript for content, including medical writing for content; and major role in the acquisition of data

\begin{tabular}{lll}
\hline Annalise & Department of Neurosciences, & Drafting/revision of the \\
Miner & University of California San & manuscript for content, \\
Diego, School of Medicine, La & including medical writing \\
Jolla & $\begin{array}{l}\text { for content; and major } \\
\text { role in the acquisition of } \\
\text { data }\end{array}$
\end{tabular}

\begin{tabular}{ll}
\hline Arthur & Department of Rheumatology, \\
Kavanaugh, & University of California San \\
MD & Diego, La Jolla
\end{tabular}

Drafting/revision of the manuscript for content, including medical writing for content; and major role in the acquisition of data

\begin{tabular}{lll}
\hline Michele & Department of Infectious & Drafting/revision of the \\
Ritter, MD & Diseases, University of & manuscript for content, \\
& California San Diego, La Jolla & $\begin{array}{l}\text { including medical writing } \\
\text { for content; and major } \\
\text { role in the acquisition of } \\
\text { data }\end{array}$ \\
& &
\end{tabular}

Jennifer S. Department of Neurosciences, Drafting/revision of the Graves, MD, University of California San manuscript for content, PhD, MAS Diego, School of Medicine, La including medical writing Jolla for content; major role in the acquisition of data; study concept or design; and analysis or interpretation of data 


\section{References}

1. Dixon L, Coughlan C, Karunaratne K, et al. Immunosuppression for intracranial vasculitis associated with SARS-CoV-2: therapeutic implications for COVID-19 cerebrovascular pathology. J Neurol Neurosurg Psychiatry. 2021;92:103-104.

2. Hanafi R, Roger PA, Perin B, et al. COVID-19 neurologic complication with CNS vasculitis-like pattern. AJNR Am J Neuroradiol. 2020;41(8):1384-1387.

3. Oliveira RMC, Santos DH, Olivetti BC, et al. Bilateral trochlear nerve palsy due to cerebral vasculitis related to COVID-19 infection. Arq Neuropsiquiatr. 2020;78(6):385-386.
4. Vaschetto R, Cena T, Sainaghi PP, et al. Cerebral nervous system vasculitis in a Covid19 patient with pneumonia. J Clin Neurosci. 2020;79:71-73.

5. Vargas G, Medeiros Geraldo LH, Gedeão Salomão N, et al. Severe acute respiratory syndrome coronavirus 2 (SARS-CoV-2) and glial cells: insights and perspectives. Brain Behav Immun Health. 2020;7:100127.

6. Paniz-Mondolfi A, Bryce C, Grimes Z, et al. Central nervous system involvement by severe acute respiratory syndrome coronavirus-2 (SARS-CoV-2). J Med Virol. 2020; 92(7):699-702. 


\section{Neurology \\ Neuroimmunology \& Neuroinflammation}

CNS Lymphocytic Vasculitis in a Young Woman With COVID-19 Infection

Garrett M. Timmons, Torge Rempe, Elizabeth A. Bevins, et al.

Neurol Neuroimmunol Neuroinflamm 2021;8;

DOI 10.1212/NXI.0000000000001048

This information is current as of July 28, 2021

\section{Updated Information \& Services}

References

Subspecialty Collections

Permissions \& Licensing

Reprints including high resolution figures, can be found at:

http://nn.neurology.org/content/8/5/e1048.full.html

This article cites 6 articles, 2 of which you can access for free at: http://nn.neurology.org/content/8/5/e1048.full.html\#\#ref-list-1

This article, along with others on similar topics, appears in the following collection(s):

Autoimmune diseases

http://nn.neurology.org//cgi/collection/autoimmune_diseases COVID-19

http://nn.neurology.org//cgi/collection/covid_19

Post-infectious

http://nn.neurology.org//cgi/collection/postinfectious_

Vasculitis

http://nn.neurology.org//cgi/collection/vasculitis

Information about reproducing this article in parts (figures,tables) or in its entirety can be found online at:

http://nn.neurology.org/misc/about.xhtml\#permissions

Information about ordering reprints can be found online:

http://nn.neurology.org/misc/addir.xhtml\#reprintsus

Neurol Neuroimmunol Neuroinflamm is an official journal of the American Academy of Neurology.

Published since April 2014, it is an open-access, online-only, continuous publication journal. Copyright

Copyright $\left({ }^{\circ} 2021\right.$ The Author(s). Published by Wolters Kluwer Health, Inc. on behalf of the American

Academy of Neurology.. All rights reserved. Online ISSN: 2332-7812.

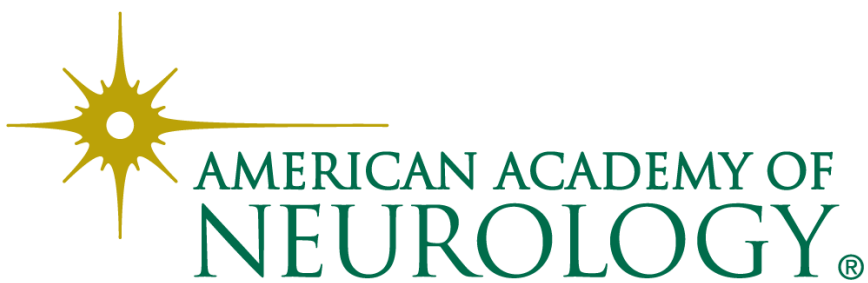

